\title{
LATE WISCONSIN ADVANCE AND RETREAT PATTERN IN THE MIAMI SUBLOBE, LAURENTIDE ICE SHEET
}

\author{
by
}

Thomas V. Lowell

(Department of Geology, University of Cincinnati, Cincinnati, OH 45221, U.S.A.)

and

\section{Robert Stuckenrath}

(Radiocarbon Laboratory, University of Pittsburgh, Pittsburgh, PA 15238, U.S.A.)

\section{ABSTRACT}

Ice-sheet advance and retreat chronologies reflect climatic change in a manner that is difficult to decipher. Especially difficult is the placement of records into a chronologic sequence. Multiple age estimates obtained from three stratigraphic positions at a site in Ohio show that organics within deposits of the Miami sublobe, along the southern margin of the Laurentide ice sheet, may be up to 3000 years older than the age of the maximum Late Wisconsin extension of that sublobe. In addition, recent studies on organic accumulations above glacial drift provide bracketing ages for ice recession. When the existing radiometric ages for the Miami sublobe are interpreted with these new radiometric constraints, several fluctuations suggested by prior workers are unsupported. A simpler chronology for the Miami sublobe suggests that in late Wisconsin time the southern margin of the Laurentide ice sheet advanced through Ohio about $22 \mathrm{ka}$ to its maximum extent at 19.7 and remained near there until $15 \mathrm{ka}$. This is in agreement with newly-refined stratigraphic histories of other Laurentide lobes.

\section{INTRODUCTION}

Late Wisconsin ice-sheet advances and retreats, whose timing comes from radiocarbon analysis of organic deposits associated with lithostratographic evidence, record major changes in climatic conditions. Although much has recently been learned about glaciogenic sedimentation, less attention has been focused on the significance of chronologic constraints used to reconstruct glacial chronologies. We discuss chronologic methodologies based on work from a site in Ohio, which allows reinterpretation of the chronology of advance and retreat of the Miami sublobe along the southern margin of the Laurentide ice sheet (Fig. 1).

Late Wisconsin advance and retreat of the Laurentide ice-sheet margin south of the Great Lakes should be a sensitive indicator of climatic conditions because of this area's relatively low latitude. Although advances may be driven by non-climatic controls (e.g. surging), recession results when ablation conditions prevail. For example, regional warming would force several sublobes of this margin to retreat in unison. A critical assessment of the chronologic associations of adjacent lobes is necessary to identify in-phase fluctuations across lobes.

Current interpretations of the Miami sublobe suggest that its margin underwent several advances and recessions between 22 and $14 \mathrm{ka}$ (Fig. 2b), including two major recessional events during the Connersville and Erie interstades (Gooding, 1975; Mörner and Dreimanis, 1973; Mickelson and others, 1983). The short time allotted for these major recessions ( $<500$ years) and subsequent readvance implies rapid climatic fluctuations between ablation and accumulation conditions.

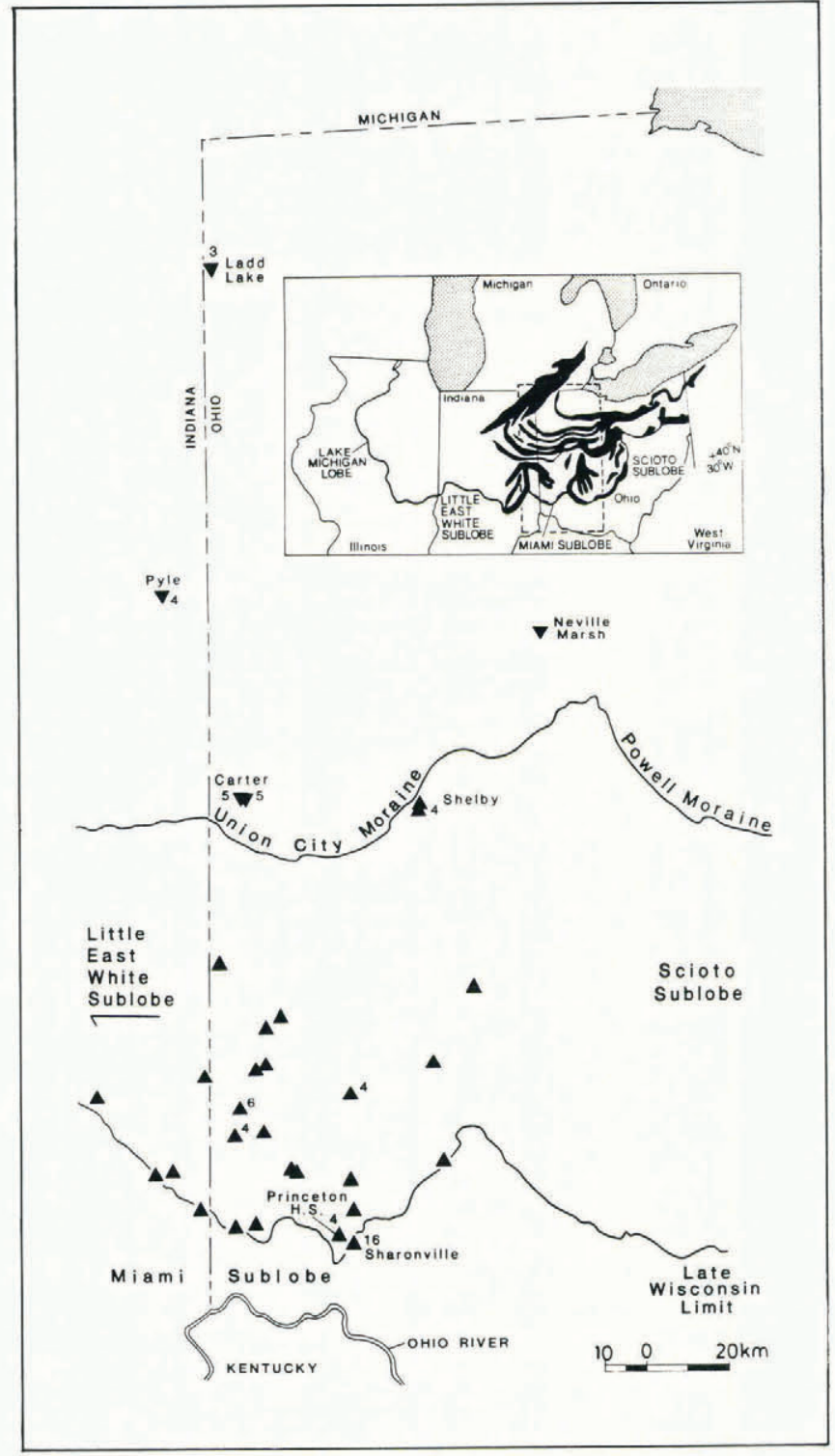

Fig. 1. Setting and distribution of radiocarbon ages in the Miami sublobe. Inverted triangles represent ages from bog or lake deposits; other triangles represent ages from below glaciogenic sediments. Sites with four or more ages are indicated with the number of ages. Data from Gooding, 1975; Mickelson and others, 1983; Shane, 1987, and personal communication, 1988; Lowell and others, in press. Only moraines near the Miami sublobe are shown. 
(A)

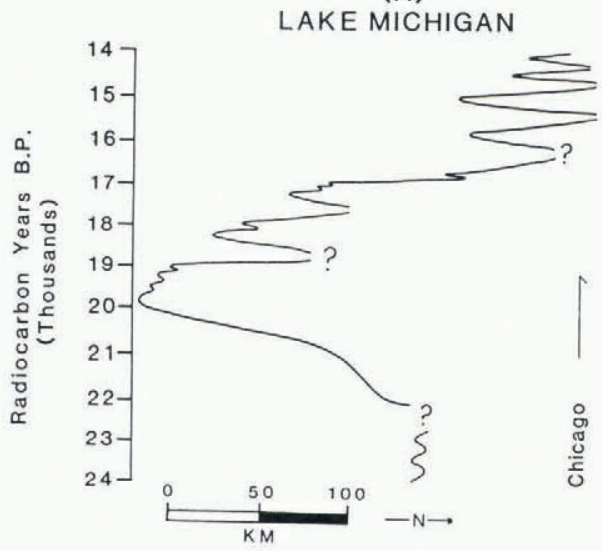

(B)

MIAMI SUBLOBE

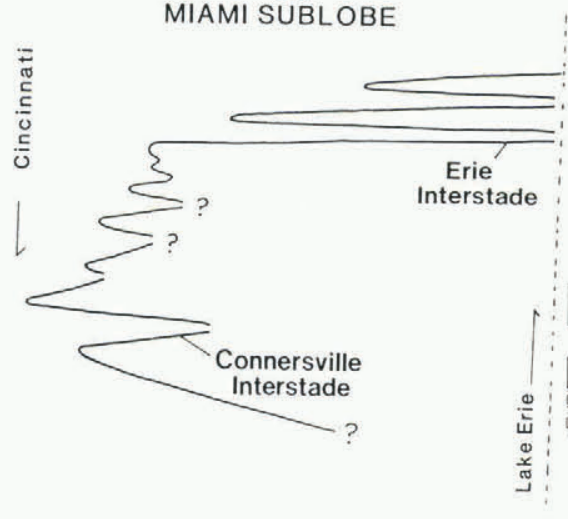

(C)

MIAMI SUBLOBE

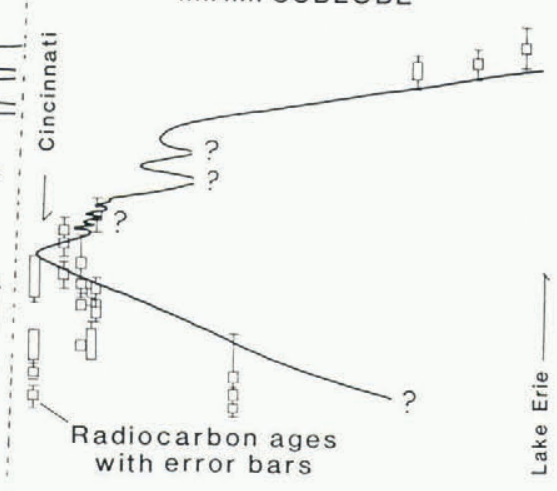

Fig. 2. Ice advance-recession models. (a) Lake Michigan lobe (after Johnson and Hansel, 1987); (b) Miami sublobe (after Gooding (1975); Mickelson and others (1983)); (c) proposed Miami sublobe.

Ongoing work in the Lake Michigan lobe further west (Fig. 1) has identified a different temporal pattern of icesheet advance and retreat (Fig. 2). If the latter history is correct, then the Lake Michigan and Miami lobes are out of phase and non-climatic causes may drive the lobe activity. On the other hand, if the present sequence of the Miami sublobe is incorrect then the lobes may be in phase and inferences might be made about climatic conditions.

\section{RADIOCARBON AGE ESTIMATES: SIGNIFICANCE TO GLACIAL CHRONOLOGIES}

Radiocarbon ages in glacial sequences provide only a limiting bracket on ice-sheet activity because plant growth is limited in the glacial environment. Organics trapped below sediments from an ice-marginal advance will be older than the advance; organics within glacial sediments must be older than the advance, and organics that become reestablished after glacial recession must be younger than the recession. Organics in each of these positions may represent a range of ages as organic material can accumulate all the time the glacier is not present. In order to evaluate the magnitude of this range we obtained multiple age estimates on organic materials in three successive stratigraphic positions at the southernmost limit of the Miami sublobe (Lowell and others, in press).

Glaciogenic deposits at our primary study site (Sharonville, Figs 1, 3a) show the following general stratigraphy from top to bottom: ablation gravels and diamictons; a diamicton with inclusions of the underlying units; thin clays; an organic mat capping organic-rich silts; a weathered portion of a lower diamicton. This sequence overlies Ordovician limestones and shales.

A)

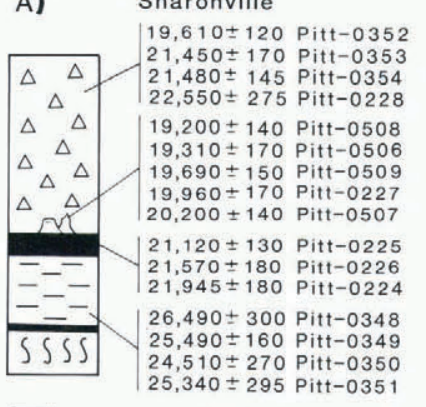

B) Princeton H.S.

$\Delta \Delta$ Diamicton $\approx$ Peat Ball

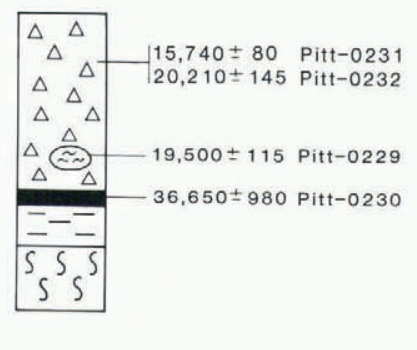

Organic Layer

Organic Silt

SSS Altered Diamicton ENT Stump cluster

Fig. 3. Simplified stratigraphy with radiocarbon ages for (a) the Sharonville site and (b) the Princeton H.S. site. No vertical scale implied.
At least seven in-situ stumps occur at the top of the silt unit; their broken tops argue that they were overrun by an ice advance. This site is significant, therefore, because (1) the death position of the stumps suggests that their age will closely limit the timing of the ice advance, and (2) the geographic position of the site constrains the time when the Miami sublobe reached its southernmost extent. Radiocarbon ages from one stump range from 19.2 to $20.3 \mathrm{ka}$ (Fig. 3a). The average age (Long and Rippeteau, 1974) for this cluster is $19670 \pm 68$ and thus we consider the advance to have occurred at that time (Lowell and others, in press).

Organic material in the organic layer around and below the stumps ranges from 21.1 to $21.9 \mathrm{ka}$ (Fig. 3a) indicating that organic material on or near the surface may yield radiocarbon ages up to 2000 years older than the overriding. Total carbon age estimates from organic silt lower in the unit range up to 6000 years older than the advance (Fig. 3a). These older dates reflect, in part, soil forming processes, and the inverted stratigraphic order here indicates probable contamination during pedogenesis.

The most revealing radiocarbon ages at the site come from wood incorporated into the diamicton overlying the stumps. These range from 19.6 to $22.5 \mathrm{ka}$ (Fig. 3a), showing that transported wood may provide age estimates nearly 3000 years older than the age of the glacial advance. That at least one of the transported logs yielded the same age as the average stump age suggests that an age for the transporting event can be estimated from several samples of transported wood. Ages from this site were generally older than the overriding glacier suggesting that the youngest age provides the best advance age. However, several ages should cluster near that age to demonstrate reliability.

At a second site less than $10 \mathrm{~km}$ away (Princeton, H.S.; Fig. 1) we obtained three age estimates from transported organics and a fourth from the underlying silt (Fig. 3b). Because the lithostratigraphic units and sequences are nearly identical we correlate these two sites; these age estimates further show the variation possible from the same event. We consider PITT-0231 (15740 \pm 80 yr B.P.) to be erroneous because (1) six age estimates from the Sharonville site and two age estimates from this site point to $19.7 \mathrm{ka}$ as the timing of the advance, and (2) it is several sigmas outside the error limits of the other advance ages from our work.

Age estimates associated wtih deglaciation have at least two problems. First, many of these come from the basal portions of lake or peat deposits that often have low organic contents and thus may be subject to contamination problems (King, 1985). Although more reliable ages may be obtained higher in the core, assumptions about sedimentation rates are needed to estimate the age at the base of the sequence. Secondly, up to 2000 years may occur after deglaciation, before organics begin to accumulate (e.g. Mickelson and Borns, 1972).

We draw three conclusions regarding the stratigraphic importance of dated organic material within glaciogenic settings. First, several ages at a site are necessary to ensure a tight bracket on a glacial advance. Secondly, transported 
wood can provide ages up to several thousand years older than the event that transported them. Thirdly, although contamination and methodology problems must be identified whenever possible, meaningful chronologic information can still be obtained when multiple ages are available.

\section{RADIOCARBON AGE ESTIMATES IN THE MIAMI SUBLOBE}

We focus on published radiocarbon ages from 25 to $10 \mathrm{ka}$ in the Miami sublobe to reconstruct its late Wisconsin fluctuations. These ages show a geographic distribution largely limited to the southern portion of the lobe, with most coming from within $50 \mathrm{~km}$ of the glacial limit (Fig. 1). The major exceptions are two sites near Sidney, Ohio, with organics below diamictons (Forsyth, 1965) and lake or bog sites spread across the lobe (Shane, 1987). Although some thirty sites have yielded radiocarbon analysis, most have only one or two ages (Fig. 1), which because of factors discussed above, provide only a coarse bracket on glacial activity.

Most of the ages range from 25 to $19 \mathrm{ka}$, with a second concentration starting after $15 \mathrm{ka}$ (Fig. 4). We point out three features of this distribution: (1) the virtual lack of ages from 18 to $15 \mathrm{ka}$; (2) the abrupt drop in the number of ages younger than $19.6 \mathrm{ka}$; and (3) the rarity of ages between 20.5 and $21 \mathrm{ka}$.

Ages younger than $15 \mathrm{ka}$ come from lake or bog sites and reflect organic accumulation since deglaciation (Shane, 1987). Shane (1987; personal communication, 1988) reported basal ages from the Carter, Stotzel-Leis (just west of Carter) and Ladd Lakes sites (Fig. 4) of $14810 \pm 170$ (Dicar-243), $14890 \pm 380-410$ (Dicar-510), and $14680 \pm$ 310 (ISGS-1679) respectively, indicating the land exposed by Miami sublobe retreat revegetated about $14.8 \mathrm{ka}$.

The three ages that lie between 18 and $15 \mathrm{ka}$ may be unrelated to glacial readvances. One age from Princeton H.S. is considered erroneous from stratigraphic and consistency considerations as noted above. The second radiocarbon age

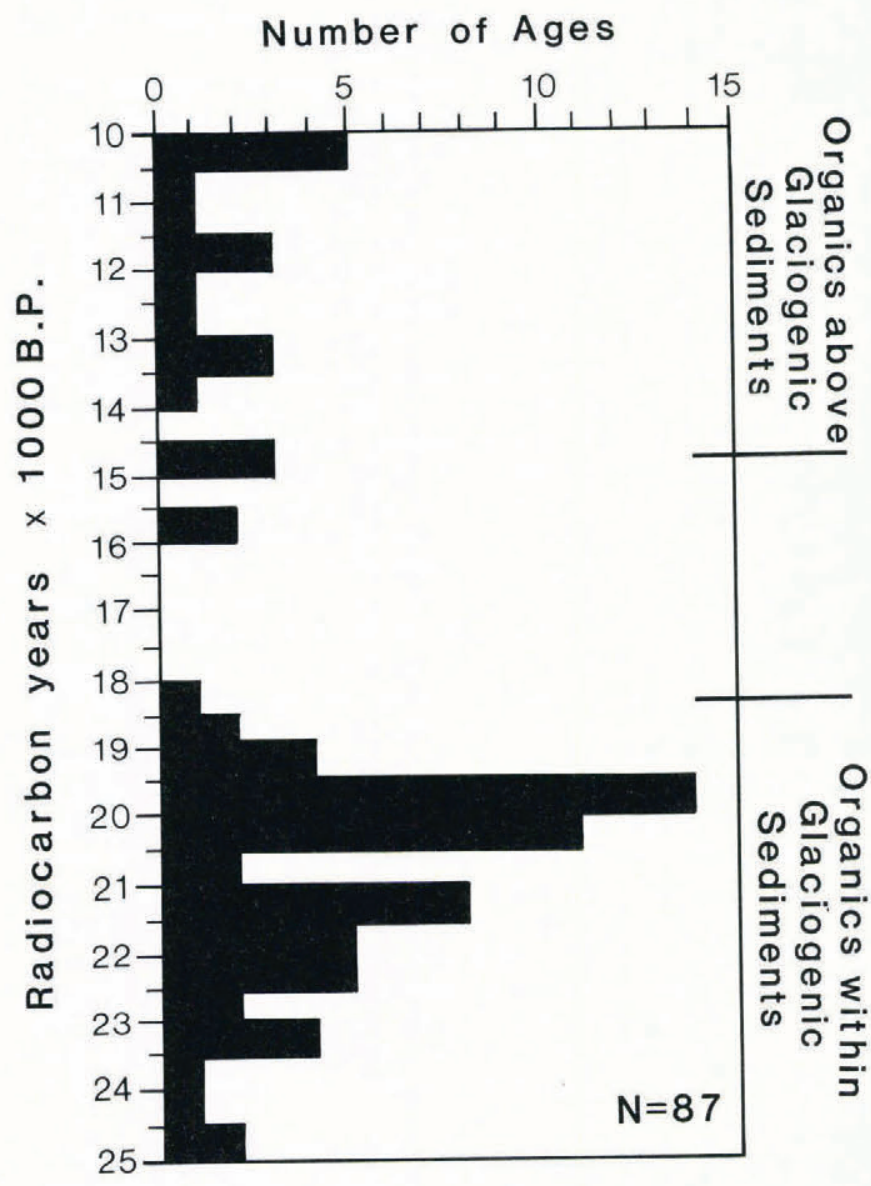

Fig. 4. Temporal distribution of radiocarbon ages in the Miami sublobe.
$(15560 \pm 230, Y-450)$ was collected in 1956 and was one of the first obtained from the Miami sublobe (Goldthwait, 1958). This estimate, like PITT-0231, lies well outside the distribution of other ages. We suggest that these two are simply statistical artifacts from the Poisson distribution of radiocarbon analysis of materials growing about 20000 yr B.P. The third age comes from organic silts with an uncertain relationship to glaciogenic activity (personal communication from B. Miller, 1988). The elimination of these three ages implies that organic material did not accumulate in the area covered by the Miami sublobe from 19.6 to $15 \mathrm{ka}$.

The paucity of ages between 20.5 and $21.5 \mathrm{ka}$ was also present in the data-set Gooding (1975) analyzed, and we believe that it led him to suggest an advance that terminated at $22 \mathrm{ka}$, subsequent recession some 50 to $80 \mathrm{~km}$, and readvance at $19.8 \mathrm{ka}$ (Fig. 2b). Although we are unsure of the reason for this gap, we feel that it probably relates to problems with the radiocarbon dating technique or sampling rather than a readvance. Moreover, readvance requires a lithostratigraphic sequence that we have not been able to replicate in our field studies.

As Mickelson and others (1983) note, and as we reiterate here, none of the existing age estimates come from deposits suggested to have formed between the first (Connersville) interstadial (at $20 \mathrm{ka}$ ) and the post-glacial deposits (younger than $15 \mathrm{ka}$ ). If several recessions and readvances occurred, why are more organics not trapped in this stratigraphic position? For example, OWU-286 (18 400 \pm 430) from wood in till is often quoted as representing readvance over an interstadial deposit (Mickelson and others, 1983). However, other ages from the same stratigraphic position at this site $(20100 \pm 265$, DIC-2608; $20480 \pm 340$, ISGS-1057; $20590 \pm 190$, ISGS-1053) combine with OWU-286 to yield an average (Long and Rippeteau, 1974) age of $20228 \pm 165 \mathrm{yr}$ B.P. We argue from a reproducibility perspective, we feel that several ages are necessary to assure an advance; and individual age can be off by several thousand years as shown by the Princeton H.S. site.

Less is known about the younger Erie interstade $(16 \mathrm{ka})$. The areal and stratigraphic position of a different diamicton are the basis for the post-Erie readvance. However, in northeastern Indiana, Wayne (1967) noted the lack of weathering and organics between the widespread uppermost drift sheets. Further, no inter-till organics have been located in northern Ohio (personal communication from R. Pavey, 1989). If the southern margin of the Laurentide underwent large-scale retreat, presumably from warm or dry climatic conditions, and subsequent readvances, this activity should have trapped organic sediments within the glaciogenic sequence. A complete lack of such organics or any other deglacial sediment casts a doubt on readvances and allows formulation of an alternate model of glacial activity for the Miami sublobe.

\section{AN ALTERNATE STRATIGRAPHY AND ITS IMPLI- CATIONS}

The existing stratigraphy suggests two major recessions of the Laurentide ice sheet (Mickelson and others, 1983) implying major ablation conditions at 20.5 and $16.0 \mathrm{ka}$. However, based on the stratigraphic context and temporal distribution of radiocarbon ages discussed above, we see little supporting evidence for either of these recessions. We suggest a simpler model with only one advance and recession.

The distribution of radiocarbon ages in the Miam sublobe suggests that it advanced across Ohio from $22 \mathrm{ka}$ to reach its southern extent at $19.7 \mathrm{ka}$. We attribute the change in diamicton lithology to a change in flow direction. Striations on islands in Lake Erie show a progressive shif in ice direction from south to southwest and finally to the west (personal communication from R. Pavey, 1989).

More problematic is the recession phase. One possibility is that gradual recession occurred in a northward direction. This would provide a time-transgressive pattern, showing the organic accumulation first in the south and later in the north. However, the existing deglaciation dates show no time lag between sites (Shane, 1987, and personal communication, 1988). More vegetation studies are needed south of the Union City Moraine to confirm this pattern. 
Forsyth and Goldthwait (1980) suggested a rapid deglaciation of the Miami sublobe, with most of the readvances being minor in extent. We extend that concept to suggest that all readvances were so minor that organic material could not accumulate between them. This implies that the area remained virtually beneath ice cover for the time span from 22 to $15 \mathrm{ka}$. The existing age estimates allow this, but a more critical test will be the study of deglacial sediments.

Johnson (in press) reports patterned ground across the Late Wisconsin drift of central Illinois, and similar features have been identified in western Indiana (Wayne, 1967). These point to cold conditions across the southern margin of the Laurentide ice sheet during the early portion of deglaciation, until the abrupt recession at $15 \mathrm{ka}$.

\section{CONCLUSIONS}

The major conclusions of this work are (1) several radiocarbon age estimates from a single stratigraphic unit are necessary to constrain the age of the unit to within the error of the analytical techniques; (2) the existing radiocarbon ages are not sufficient to support the currently accepted complex sequence of advances, recessions, and readvances of the Miami sublobe; and (3) a stratigraphic history of the Miami sublobe that involves continued ice cover from $22 \mathrm{ka}$ until rapid deglaciation at $15 \mathrm{ka}$ is a viable alternate hypothesis. If our third conclusion is correct, it brings the chronology of the Miami sublobe more in line with the recently refined stratigraphies in the Lake Michigan lobe (Johnson and Hansel, 1987, fig. 1). This in turn implies that the Laurentide ice sheet remained near its southern extent until $15 \mathrm{ka}$. An extended ice margin suggests that relatively stable mass balance conditions persisted over that time and that mechanically forced "surges" are not as evident as in previous interpretations.

\section{ACKNOWLEDGEMENTS}

Support for this work comes from the University of Cincinnati Research Council and the College of Arts and Sciences. We thank L. Shane for the use of unpublished radiocarbon analyses and two referees for suggesting several improvements.

\section{REFERENCES}

Forsyth, J.L. 1965. Age of buried soil in the Sidney, Ohio area. Am. J. Sci., 263, 571-597.

Forsyth, J.L. and R.P. Goldthwait. 1980. Rapid Late Wisconsin deglaciation of western Ohio. American Quaternary Association Abstracts and Programs, 6, 80-81.

Goldthwait, R.P. 1958. Wisconsin age forests in western Ohio: I. Age and glacial events. Ohio J. Sci., 58(4), 209-219.

Gooding, A.M. 1975. The Sidney Interstadial and Late Wisconsin history in Indiana and Ohio. Am J. Sci., 275 , 993-1011.

Johnson, H.W. 1990. Ice-wedge casts and relic patterned ground in central Illinois and their environmental significance. Quat. Res., 33, 51-72.

Johnson, H.W. and A. Hansel. 1987. Fluctuations of the Late Wisconsinan (Woodfordian) Lake Michigan Lobe in Illinois, U.S.A. International Union for Quaternary Research Program with Abstracts, XII Congress, 195.

King, G.A. 1985. A standard method for evaluating radiocarbon dates of local deglaciation: application to the deglaciation history of southern Labrador and adjacent Québec. Géogr. Phys. Quat., 39(2), 163-182.

Long, A. and B. Rippeteau. 1974. Testing contemporaneity and averaging radiocarbon dates. Am. Antiq., 39, 205-215.

Lowell, T.V., K.M. Savage, C.S. Brockman, and R. Stuckenrath. In press. Radiocarbon analyses from Cincinnati, Ohio and their implications for glacial stratigraphic interpretations. Quat. Res.

Mickelson, D.M. and H.W. Borns, jr. 1972. Chronology of a kettle-hole peat bog, Cherryfield, Maine. Geol. Soc. Am. Bull., 83, 827-832.

Mickelson, D.M., L. Clayton, D.S. Fullerton, and H.W. Borns, jr. 1983. The Late Wisconsin glacial record of the Laurentide ice sheet in the United States. In Porter, S.C., ed. Late Quaternary environments of the United States. Minneapolis, MN, University of Minnesota Press, 3-37.

Mörner, N.-A. and A. Dreimanis. 1973. The Erie Interstade. In Black, R.F., R.P. Goldthwait, and H.B. Willman, eds. The Wisconsinan Stage. Geol. Soc. Am. Mem., 136, 107-134.

Shane, L.C.K. 1987. Late-glacial vegetational and climatic history of the Allegheny Plateau and the till plains of Ohio and Indiana, U.S.A. Boreas, 16(1), 1-20.

Wayne, W.J. 1967. Periglacial features and climatic gradient in Illinois, Indiana, and western Ohio, east-central United States. In Cushing, E.J. and H.E. Wright, jr, eds. Quaternary paleoecology. New Haven, CT, Yale University Press, 393-414. 